\title{
Truth and the Novel
}

\author{
Merilyn Moos
}

It was not till late middle age that I finally found out about my family's past. My parents had hidden it with reason. I had been aware that ours was a particularly small family, but my father had told me - and it was a legend I embraced eagerly - that he had fled Nazi Germany because of his radical theatre activities, walking his way from Berlin to France. From Paris, my parents had come to London.

It was when my mother, already in her $90 \mathrm{~s}$, went into hospital, that I got hold of their old letters and documents. The first letters I found lying on the table in the downstairs room, as if she had wanted me to read them. Grey bits of paper, thin as tissue, all crumpled up together, all in German. And so began my adventures into the tunnel of the past.

Every further revelation left me more unstable, more unsure of who I was. I started to write a novel, maybe to help me understand, to help build from the fragments. Here I started to catch sight of my parents, who had wrapped themselves in a shroud of forgetfulness. Here I could talk with those whose premature deaths had robbed me of the chance to say 'hullo.' I spoke to the pages. And they spoke back to me. The 'fictional' characters started to chatter in my ear and to chide me if I got their lines wrong. They would insist on telling me what they wanted me to know about them. My family started to emerge before me, and no longer as weighed down by silence, I too began to unfold and touch bits of myself that had long lain hidden. In these pages, I could be alive, myself.

Why a novel? Why not write an autobiography or biography? My parents' lives were certainly remarkable enough to deserve a biography, mine strange enough to interest as an autobiography. But facts were few and far between. And what 'facts' there were, were the edifices my parents had built to shut out too much remembering. I had to search for a past 
which had framed my whole being yet which I knew nothing of. I wanted to explore with my rational mind half closed, to go wandering along the byways of memory where seeking only 'facts' would close the gates to understanding.

I met my maternal grandparents for the first time reading the letters they had sent my parents but it was in my imagination that I started to take small peeks at them. Their letters became ever more desperate as the Nazis' anti-Semitism became more ferocious. At first they wrote of table cloths and gabardines, by 1939, they appeal: Get us out of here. I could only read a little at a time, as their words pushed me down into imaginings of what had happened to them. I wanted to reach out and tug them from the pages of history into the light of the present day. So I got to know them in the pages of my novel. Not them of course. I never knew them. Never even knew of them. The little my mother told me were lies (well-meant but unhelpful). It was in my novel that I wrote them letters to which they replied. I could only have done that in a novel. I could let them tell me what I knew they wanted to say. I could write that I wanted to save them.

But writing also allowed me to put myself outside of myself, seeking the truth not bound by the trivia of the every day. No auto/biography can ever tell the 'truth.' What facts shall be chosen? Shall I tell of the Christmas when my father wept silently over the Christmas tree or when my mother threw the chicken at me? No room for both. But in a novel the reader knows the story has been crafted. No need to dance around a historical reality. I can write of the essence. I can write of a mother so exhausted by death that she can no longer cry tears. Of her child deafened by her parents' silences and inability to tell the truth, who, now middle aged, still does not know if she can trust a word anybody ever says.

The novel also crucially gave me the scope to write of four generations of one family, about how what happened to the grandparents slid down the arteries of time into the veins of their great-grandson, how the effects of exile from Nazism (and Stalinism) continued to cramp and distort the generations that came after. The novel allowed me to turn history into daily lived experience.

Not that writing a novel did not have its problems. Readers like to know what is true and what made up, and can find a novel which dances about on the pinhead of truth a trifle disconcerting. Which bits are true, a friend asked me, arriving at my home with his book heavily marked over the passages he was particularly concerned over. Another friend was incredulous at the successful interweaving of 'fact 'and 'fiction.' A former boyfriend, spotting bits of what he knew of me in the novel, falsely assumed that he was the model for one of the (entirely fictitious) lovers and became exceedingly irate at my impudence. 
There were more serious concerns. What would my (very small) family think of my washing dirty linen in public? Would calling it fiction soothe their deeply felt anxieties? Not upsetting them mattered to me, and it was one reason for choosing the format of a novel. Then there was the question of what to do about my grandparents' letters. Was I diminishing them by putting their letters, real primary data, ones of such historical and emotional significance, into a novel? It took me years to resolve this - but in the end, there they lie, an honour to my grandparents and a crucial part of the story. Indeed, many novels crafted around the Second World War and other experiences of persecution, dispossession and trauma, do similarly.

My novel is a story about the personal impact of the cataclysmic events of the twentieth century and it is painful. It is also an all too typical tale of the human condition. It was a blow when nobody would publish it. It did not help that at my age, it was supposed that I would not have many more books in me, and so was not really worth all that marketing hype. And I was a woman which statistically put me at a serious disadvantage. The final nail in my coffin was however that this was a novel that did not fit any easy category - where would it go on the shelves of the bookshop - historical, literary, even women's literature? In the end I self-published in 2010 and have subsequently received many glowing reviews.

It is a mistake, especially in these postmodernist days, to think of the novel as having a rigid form. The novel is a fluid category that does not need to be bound by inflexible traditions - though this is not a justification for sloppy writing or loose form. In a century of European ferment, it is not surprising that the European novel should also be in transition.

Finally I want to illustrate the power and versatility of the novel by an extract from Chapter 61, which lies towards the end of the book. In this passage, I imagine the grandfather I knew nothing of.

Anna, the main character and narrator, has just read the very last of the (real) letters from Johann to his daughter. Johann's wife, Rosa, has recently died a probably natural death.

The italics signify Anna's imagining her unknown grandfather throughout the novel.

'I try to hear you, Johann. I'm reading your last letters from 1942. Every word is weighed.

No more appeals from you to be allowed to leave. It is too late, and you know it. You are living through a novel stage of horror. When you write, 'I 
am still at my old address,' I know you are warning Louise that 'they' are trying to get you out. You're afraid. You weren't allowed to stay at the old address for long.

You say to yourself: at least my darling Rosa was spared this. That is something to celebrate. I could not have protected you, my liebschen. At least, we have the comfort that our children, Emil and Louise are safe. That alone is a blessing.

He is sitting in the heavy armchair, which he had asked a younger neighbour to move for him, so that he can see out of the window onto the lime trees. He regrets the absence of the lacy doily which used to hang over the back of the chair, protecting it from wear. His collar is rubbing his neck. Can't be because he's getting any fatter. He remembers how Rosa always had a supply of fresh collars...

'If only, Louise, you hadn't got involved in all that mischief,' he thinks. 'You were the baby of our family, our favourite.' He smiles at the memory of the little girl who always had her head in a book. Just like him. 'You left us so young. We hardly had time to get to know you before you were off on your own path. You were always a bit of a rebel, weren't you, Louise?' and he smiles again, seeing her standing before him. 'You fly too close to the sun,' he warns her. 'Beware. But I shall always be here for you,' he starts to tell her. Then he stops. He strokes the top of his high, bald-domed head. 'Louise, come to me', he calls out aloud, 'before it is too late. Louise, can you hear me?' And he buries his handsome head in his hands and weeps.'

Merilyn Moos's novel 'The Language of Silence' can be purchased from Amazon, reputable bookshops, or from her at merilynmoos@ blueyonder.co.uk.

\section{THE AUTHOR}

I was born in 1944 in Oxford to German political refugee parents, grew up in Durham where I attended the Grammar School, returned to Oxford to study PPE, subsequently obtained an MA in Cultural Studies at CCCS, became a lecturer, a trade union activist and had published a large variety of articles on education. The birth of my child and becoming an unplanned single parent provoked a greater interest in my family's hidden past, the results of which are reflected in my recent novel: 'The Language of Silence', referred to in this article. I have had a good number of articles published recently on the issues around being second generation i.e. being the 'child' of refugees from Nazism. Recently retired, I am presently finishing two books: on the second generation in the UK and a biography of my father, and will then return to writing novels. 